\title{
MILDEW LOCUS O Mutation Does Not Affect Resistance to Grain Infections with Fusarium spp. and Ramularia collo-cygni
}

\author{
Katharina Hofer, Andrea Linkmeyer, Katharina Textor, Ralph Hückelhoven, and Michael Hess
}

Lehrstuhl für Phytopathologie, Technische Universität München, Emil-Ramann-Str. 2, D-85354 Freising, Germany.

Accepted for publication 6 April 2015.

\begin{abstract}
Hofer, K., Linkmeyer, A., Textor, K., Hückelhoven, R., and Hess, M. 2015. MILDEW LOCUS O mutation does not affect resistance to grain infections with Fusarium spp. and Ramularia collo-cygni. Phytopathology 105:1214-1219.

MILDEW LOCUS $O$ defines a major susceptibility gene for powdery mildew, and recessive mlo resistance alleles are widely used in breeding for powdery mildew resistance in spring barley. Barley powdery mildew resistance, which is conferred by mlo genes, is considered to be costly in terms of spontaneous defense reactions and enhanced susceptibility to

cell-death-inducing pathogens. We assessed fungal infestation of barley (Hordeum vulgare) grain by measuring fungal DNA after natural infection with Fusarium spp. and Ramularia collo-cygni or after inoculation with Fusarium spp. in the field. Powdery-mildew-resistant mlo5 genotypes did not show enhanced Fusarium spp. or $R$. collo-cygni DNA content of grain over four consecutive years. Data add to our understanding of pleiotropic effects of mlo-mediated powdery mildew resistance and contributes to the discussion of whether or not application of barley mlo mutations may support pathogenesis of cell-death-inducing fungal pathogens under field conditions.
\end{abstract}

Durable disease resistance is, in addition to yield, one of the most important traits in plant breeding (Summers and Brown 2013). However, there are reports about a possible trade-off between disease resistance and yield (Purrington 2000). Genetic resistance to biotrophic pathogens might come with pleiotropism with regard to enhanced susceptibility to hemibiotrophs or necrotrophs. A prominent example for pleiotropism is the MILDEW LOCUS O (mlo) powdery mildew (Blumeria graminis $\mathrm{f}$. $\mathrm{sp}$. hordei) resistance locus in barley (Hordeum vulgare). The $M L O$ wild-type (WT) allele codes for a negative regulator of plant defense (Büschges et al. 1997), whereas loss-of-function mutations in $M L O$ implement recessively inherited, monogenic, race-nonspecific, and durable resistance against barley powdery mildew (Jørgensen 1992) by reducing fungal penetration success (Stolzenburg et al. 1984).

In addition to this benefit, mlo resistance is known to come along with detrimental effects in terms of yield (Kjær et al. 1990). The spontaneous occurrence of necrotic leaf lesions on mlo mutants results in reduced grain number per stem (Thomas et al. 1998) and thousand-kernel weight (Hackett et al. 2001). Because this phenomenon was identified as a pleiotropic effect (Jørgensen 1992), breeders were able to produce high-yielding powdery-mildewresistant barley mlo varieties by rearranging genes in other parts of the genome (Brown 2002).

Other trade-offs were documented for mlo resistance in barley with regard to susceptibility to nonbiotrophic pathogens. Most of the published data suggest increased susceptibility of mlo mutants to hemibiotrophic and necrotrophic fungi. Detached-leaf assays with plants of near-isogenic backcross (BC) lines revealed greater susceptibility of genotypes carrying a recessive mlo gene compared with WT individuals when inoculated with the hemibiotrophic rice blast pathogen Magnaporthe oryzae (Jarosch et al. 1999) or when infiltrated with toxic culture filtrates of the barley leaf spot blotch

Corresponding author: M. Hess; E-mail address: m.hess@tum.de

*The $e$-Xtra logo stands for "electronic extra" and indicates that three supplementary tables are published online.

http://dx.doi.org/10.1094/PHYTO-12-14-0381-R

(C) 2015 The American Phytopathological Society fungus Bipolaris sorokiniana (teleomorph: Cochliobolus sativus) (Kumar et al. 2001). Jansen et al. (2005) conducted experiments in which detached barley spikes and caryopses were inoculated with Fusarium graminearum, resulting in increased susceptibility of mlo mutants when compared with $M L O$ WT. Both, B. sorokiniana and $F$. graminearum, are often considered to be necrotrophic, because they produce host-nonspecific toxins. However, B. sorokiniana can also penetrate living host cells (Schäfer et al. 2004) and $F$. graminearum can grow symptomless between cells or between the cuticle and the cell wall (Brown et al. 2010; Linkmeyer et al. 2013). Makepeace et al. (2008) obtained conflicting data for the Ramularia (Ramularia collo-cygni) leaf spot disease (RLS) when inoculating barley seedlings under different light regimes. RLS has a long period of latency. The pathogen behaves like an endophyte until it switches to a necrotrophic lifestyle, which is likely triggered by host developmental cues (Havis et al. 2015). Pallas MLO WT plants were more heavily diseased in conditions without nearultraviolet light than plants of its near-isogenic BC line, containing the mlo5 resistance gene, which represents a functional null allele (Büschges et al. 1997). This was reversed in conditions with near ultraviolet light. However, a previous study, visually assessing the diseased leaf areas, showed reduced rather than enhanced susceptibility of mlo genotypes to RLS in the field (Makepeace et al. 2007). Barley mlo lines also show enhanced abiotic flecking (Brown and Rant 2013; Makepeace et al. 2007), which can be difficult to distinguish from RLS symptoms. Other field trials with regard to RLS resulted in enhanced RLS leaf symptom scores for genotypes containing recessive mlo alleles compared with plants with the WT $M L O$ alleles (Pinnschmidt and Sindberg 2009). This was confirmed and further supported with the use of near-isogenic mlo BC lines in controlled environments (McGrann et al. 2014). Apart from those experiments, which specifically addressed the role of mlo, data from field trials are lacking regarding susceptibility of mlo mutant genotypes to pathogens other than powdery mildew. Studies with intact mlo plants instead of excised plant organs and experiments with quantification of present fungal biomass or DNA appear underrepresented. Measurements of fungal DNA appear to be an appropriate tool to assess infestation rates, particularly when symptoms are absent or unspecific. For instance, symptoms can 
either be unspecific, as for Fusarium spp. on barley (Tekauz et al. 2000 ), or difficult to quantify by visual methods, as for $R$. collocygni (Havis et al. 2015).

Fusarium head blight (FHB) of small grain cereals such as barley is caused by a complex of Fusarium spp. In spite of an international predominance of $F$. graminearum, $F$. culmorum, and $F$. avenaceum (Parry et al. 1995), the structure of pathogen spectra can differ between countries and include also $F$. sporotrichioides, $F$. tricinctum (Bottalico and Perrone 2002), F. langsethiae (Torp and Nirenberg 2004), and others. The damage caused by FHB is multifactorial and has relevance for barley comparable with that for wheat. On the one hand, FHB is capable of causing yield reduction (McMullen et al. 1997). Although yield damage potential on wheat appears more severe than on barley, reports from the 1990s documented appreciable yield losses in Northern Great Plains' barley production (Windels 2000). On the other hand, quality reductions with regard to baking, brewing, and seed features result from Fusarium infections (Parry et al. 1995). In addition, several Fusarium spp. have the potential to produce a range of mycotoxins (Bottalico and Perrone 2002) with negative effects on human and animal health (Bennett and Klich 2003). Consequently, yield and quality losses result in direct and secondary economic damages. In the period of 1993 to 1998 , barley producers in North Dakota, South Dakota, and Minnesota had to register a total net revenue loss caused by FHB of $\$ 406$ million (Windels 2000). Production and price losses for barley producers in North Dakota added up to $25.7 \%$ in the period of 1998 to 2000 (Nganje et al. 2002).

FHB is known as a largely soilborne disease (Parry et al. 1995). Fusarium pathogens have the capability to overwinter and grow saprophytically on harvest residues (Jenkinson and Parry 1994). Plant infection may occur when cereal seed are sown into infested soil. This could lead to Fusarium seedling blight and Fusarium foot rot. At advanced stages of the vegetation period, airborne inoculum and rain splash can infect the spikes of plants and cause FHB. As an alternative to harvest residues, Fusarium spp.-infested grains as seed material can transmit the pathogen into the next season (Parry et al. 1995).

$R$. collo-cygni is likely distributed by airborne conidia released from typical swan-neck-shaped conidiophores (Havis et al. 2015). In addition, seed transmission is considered to be an important inoculum source with regard to epidemiology and perceived as a challenge for disease control and quarantine (Havis et al. 2011). RLS on barley has been an increasing problem since the end of the 1990s and may affect other cereal crops (Walters et al. 2008). RLS leads to a loss of green leaf area by causing reddish-brown lesions. Barley yield reductions caused by RLS can add up to $40 \%$ (Oxley and Havis 2004).

Under German production conditions, RLS causes high yield losses but FHB only moderately reduces yield in spring barley. However, both Fusarium spp. and $R$. collo-cygni can be seed transmitted and threaten malting quality of spring barley grain (Havis et al. 2015; Windels 2000).

Because mlo resistance in barley is known to have pleiotropic effects on the susceptibility toward necrotrophic and hemibiotrophic pathogens, the present study investigates whether mlo powdery mildew resistance enhances infestation of barley kernels with Fusarium spp. and $R$. collo-cygni DNA in spring barley grain when produced under natural environment conditions.

\section{MATERIALS AND METHODS}

Field experiment. Fundamentals. A quadrennial field experiment (2010-2013) was carried out including various spring barley varieties and Fusarium inoculation treatments (Supplementary Table S1). Because of the naturally high disease pressure in this region additional inoculation with $R$. collo-cygni was not necessary. The single field trials were carried out in Freising (Germany, $450 \mathrm{~m}$ above sea level, average temperature $7.7^{\circ} \mathrm{C}$, average precipitation
$814 \mathrm{~mm}$, silt loam) by using microplots (double rows, $80 \mathrm{~cm}$ long, $17-\mathrm{cm}$ row spacing, $30-\mathrm{cm}$ plot spacing, 40 seeds/plot). Plant protection, growth regulation, and fertilization were carried out according to regional standard application rates. Matured plants (growth stage [GS] 92 to 95) were manually harvested and dried for 7 to 14 days in paper bags. Threshing took place with a single-spike thresher. Until further processing, generated grain material was stored in paper bags at room temperature.

Varieties or lines. The field trial included spring barley 'Ingrid' and 'Pallas' and their corresponding near-isogenic, powdery-mildewresistant BC lines, BC Ingrid-mlo5 and BC Pallas-mlo5. The tested lines of both Ingrid and Pallas were considered to be susceptible to FHB and RLS because symptoms of both diseases could be observed in preliminary tests.

Inoculation. For a facilitated inoculation handling, the trial setup provided a split-plot randomized complete block design, each block consisting of three to six replications of every variety or line. Corresponding blocks were spray inoculated with spore suspensions of F. culmorum (2010 to 2013), F. graminearum (2013), F. avenaceum (2010 and 2013), F. tricinctum (2013), F. langsethiae (2013), and F. sporotrichioides (2010 and 2013). A control block remained noninoculated. Spore densities reached from $1 \times 10^{6}$ and $1 \times 10^{7}$ conidia/ $\mathrm{m}^{2}$ (2013) through $3.6 \times 10^{7}$ conidia $/ \mathrm{m}^{2}$ (2010 and 2011) up to $7.5 \times 10^{7}$ conidia/m² $(2012)$. The application was carried out twice within 7 days in the time period of mid- to late anthesis of plants (GS 65 to 69) using a backpack sprayer (pressure: 2.1 bar, nozzle type: 110/04).

Preparation of fungal material and inoculum suspensions. Single-spore isolates of $F$. culmorum ( $\mathrm{Fc002}$ and $\mathrm{Fc} 03$ ), F . graminearum (Fg07), F. avenaceum ( $\mathrm{Fa001}$ and $\mathrm{Fa} 002)$, F tricinctum ( $\mathrm{Ft} 001$ and Ft01b), F. langsethiae (Fl001 and Fl002), and F. sporotrichioides (Fs002 and Fs01) were acquired, propagated, and processed to inoculum suspensions as described by Linkmeyer et al. (2013). All isolates derived from barley grain grown in Germany (Fc002, Fg07, Fa001, Fa002, Ft01b, Fl001, Fl002, Fs002, and Fs01), Denmark (Ft001), or Poland (Fc03).

Measurement of pathogen infestation. Isolation of genomic DNA from barley grain. Of the total yield (approximately 60 to $100 \mathrm{~g} /$ microplot), a grain subsample of $50 \mathrm{~g}$ per microplot was ground to fine powder using a laboratory mill. Isolation of DNA from barley grain material followed recommendations of the European Community Reference Laboratories (Joint Research Centre 2007) for the isolation of maize DNA, including some modifications described by Linkmeyer et al. (2013).

Quantification of genomic DNA in barley grain. To ascertain DNA amounts of Fusarium spp. in grain deriving from inoculated and control plots, a quantitative polymerase chain reaction (qPCR) protocol for fungal and barley DNA was accomplished on the basis of Nicolaisen et al. (2009) adopted by Linkmeyer et al. (2013). Amplification of DNA was carried out in a total volume of $20 \mu \mathrm{l}$ containing $10 \mu \mathrm{l}$ of $2 \times$ Maxima SYBR Green qPCR Master mix (Fermentas, St. Leon-Rot, Germany), forward and reverse primer at $300 \mathrm{nmol} / \mathrm{liter}$ each, $10 \mu \mathrm{g}$ of bovine serum albumin, and $100 \mathrm{ng}$ of genomic DNA. PCR amplification was performed in duplicates in an MX3000P Cycler (Stratagene, Santa Clara, CA). The thermal profile started with an initial step at $50^{\circ} \mathrm{C}$ for $2 \mathrm{~min}$ and $95^{\circ} \mathrm{C}$ for $10 \mathrm{~min}$, followed by 40 cycles of $95^{\circ} \mathrm{C}$ for $15 \mathrm{~s}$ and $60^{\circ} \mathrm{C}$ for $1 \mathrm{~min}$. Subsequent melting curve measurement was performed at 55 to $95^{\circ} \mathrm{C}$. In addition to specific primers for Fusarium spp. (FgramB379fwd/FgramB411 rev, FculC561fwd/FculC614rev, FspoA18 fwd/FspoA85rev, FlangA29fwd/ FlangA95rev, Fave574fwd/Fave627rev, and Ftri573fwd/Ftri630rev) a barley DNA assay was included for normalization (Hor1f/Hor2r). An external standard calibration was carried out to accomplish absolute quantification of barley and Fusarium DNA. For that purpose, dilution series (100,10, 1, 0.1, and $0.01 \mathrm{ng}$ of DNA) of pure fungal and barley DNA were generated and included in the qPCR assay. Fusarium DNA was diluted in fungal DNA-free barley DNA at $20 \mathrm{ng} / \mu \mathrm{l}$ to mimic matrix effects in DNA samples extracted from 
barley grain material. Individual qPCR assays were verified for reproducibility, specificity, and sensitivity in our lab according to Nicolaisen et al. (2009) (Linkmeyer 2012).

Quantification of $R$. collo-cygni DNA in grain deriving from noninoculated control plots occurred by using the Taq-Man qPCR protocol of Taylor et al. (2010), including some modifications: PCR assays were performed in a total volume of $25 \mu$ l containing $1 \times \mathrm{iQ}$ Supermix (Bio-Rad, Hercules, CA), $400 \mathrm{nmol}^{-1}$ forward and reverse primer (RamF6/RamR6), $150 \mathrm{nmol}^{-1}$ Ramularia probe (FAM; Ram6), $5 \mu \mathrm{l}$ of DNA template $\left(20 \mathrm{ng}^{-1} \mathrm{l}^{-1}\right)$, and PCR-grade water to make up the final volume. To confirm the reproducibility, PCR amplification was performed in duplicates using a MX3000P Cycler (Stratagene). Nuclease-free water was utilized for negative (no template) control.

The thermal profile started with an initial step $10 \mathrm{~min}$ at $95^{\circ} \mathrm{C}$ and was followed by 48 cycles of $95^{\circ} \mathrm{C}$ for $20 \mathrm{~s}, 55^{\circ} \mathrm{C}$ for $20 \mathrm{~s}$, and $72^{\circ} \mathrm{C}$ for $20 \mathrm{~s}$. A final extension step of $95^{\circ} \mathrm{C}$ for 1 min completed the profile. Absolute quantification of $R$. collo-cygni DNA was performed by external standard calibration. Therefore, dilution series of DNA from $R$. collo-cygni culture were generated $(0.128$, $0.64,3.2,16,80,400,2,000$, and 10,000 pg) and served as standard rows. Reproducibility, specificity, and sensitivity of the qPCR assay were reproduced in our lab according to Taylor et al. (2010).

Definition of inoculation success. To measure the inoculation success, DNA amounts of corresponding Fusarium spp. gave detailed information about the achieved infestation levels. Inoculation success was defined as significant increase $(P \leq 0.05)$ of DNA amount in inoculated plots compared with noninoculated control plots.

Statistics. Generated data were collected and prepared with Microsoft Excel 2010. Statistical operations were carried out with IBM SPSS 21 statistics. Analyses of variance using the Tukey B test $(P \leq 0.05)$ were conducted to compare means of multiple data sets.

\section{RESULTS}

To test the influence of the mlo5 gene on Fusarium infection, Fusarium pathogen pressure was artificially increased by inoculation with spore suspensions. Quantification of fungal biomass by qPCR analysis was used to measure fungal infection and inoculation success, because symptom formation on barley is unspecific for Fusarium spp. and R. collo-cygni infection (see below) on barley spikes is difficult to visually assess.

In 2010, we spray inoculated with spore suspensions of F. culmorum, F. avenaceum, and F. sporotrichioides, which produce different types of mycotoxins, in the field. All three inocula significantly and strongly enhanced fungal DNA content of the respective Fusarium spp. in harvested grain (Table 1). In 2013, we additionally included inoculum of $F$. graminearum, $F$. tricinctum, and $F$. langsethiae to test species frequently appearing and considered as important barley pathogens. However, inoculation success was detectable in 2013 only for F. culmorum, F. sporotrichioides, and $F$. graminearum but not for $F$. avenaceum, $F$. tricinctum, and F. langsethiae (Table 2).

Influence of mlo5 on Fusarium infections. We compared Fusarium DNA amounts in barley grain of parent $M L O$ Pallas or Ingrid and BC mlo5 lines grown in naturally infected control plots and after spray inoculation in the field. This displayed higher natural inoculum pressures in 2010 than in 2013, as reflected by Fusarium DNA contents. In 2010, the Pallas background appeared slightly more susceptible to natural grain infestation by Fusarium spp. than the Ingrid background (Table 1). However, at the lower natural disease pressure in 2013, this difference was not visible any more (Table 2). Without artificial inoculation in the field, BC mlo5 lines of Pallas or Ingrid were not significantly more or less infested with Fusarium spp. than WT MLO parent lines (Tables 1 and 2; Supplementary Table S3).

After spray inoculation in the field, BC mlo5 lines appeared generally less infested with single Fusarium spp. in 2010. This effect was consistent in tendency and seen in both genetic backgrounds. It was statistically significant for F. culmorum between WT $M L O$ lines and $\mathrm{BC}$ mlo5 lines regardless of the Pallas or Ingrid background (Table 1). For F. avenaceum, enhanced infestation of BC mlo5 genotype was statistically significant only in the background of Ingrid. For F. sporotrichioides, no statistically significant difference in fungal DNA in grain of $M L O$ versus $\mathrm{BC}$ mlo5 genotypes was observed. The tendency of reduced susceptibility of BC mlo5 lines to grain

TABLE 1. Fusarium spp. DNA in grain of spring barley genotypes in $2010^{\mathrm{z}}$

\begin{tabular}{|c|c|c|c|c|c|c|c|c|}
\hline \multirow[b]{3}{*}{ Inoculum } & \multicolumn{8}{|c|}{ Fusarium spp. DNA in pg/ng of barley DNA } \\
\hline & \multicolumn{2}{|c|}{ Ingrid } & \multicolumn{2}{|c|}{ BC Ingrid-mlo5 } & \multicolumn{2}{|c|}{ Pallas } & \multicolumn{2}{|c|}{ BC Pallas-mlo5 } \\
\hline & Cont & Inoc & Cont & Inoc & Cont & Inoc & Cont & Inoc \\
\hline Fusarium culmorum & $0.66 \mathrm{a}$ & $118.03 \mathrm{c}$ & $1.95 \mathrm{a}$ & $61.86 \mathrm{~b}$ & $2.79 \mathrm{a}$ & $117.33 \mathrm{c}$ & $3.10 \mathrm{a}$ & $68.59 \mathrm{~b}$ \\
\hline F. avenaceum & $1.71 \mathrm{a}$ & $34.68 \mathrm{c}$ & $2.84 \mathrm{a}$ & $19.42 \mathrm{~b}$ & $3.75 \mathrm{a}$ & $43.63 \mathrm{c}$ & $4.01 \mathrm{a}$ & $34.01 \mathrm{c}$ \\
\hline F. sporotrichioides & $0.24 \mathrm{a}$ & $32.82 \mathrm{~b}$ & $0.24 \mathrm{a}$ & $23.64 \mathrm{~b}$ & $0.11 \mathrm{a}$ & $31.52 \mathrm{~b}$ & $0.47 \mathrm{a}$ & $33.12 \mathrm{~b}$ \\
\hline
\end{tabular}

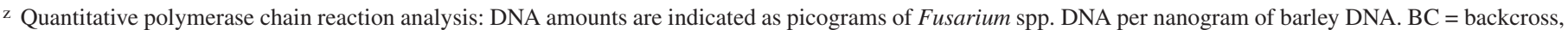
Cont $=$ control, and Inoc $=$ inoculated. Statistically significant differences in DNA amounts in rows are marked by different letters according to analyses of variance results. Inoculation success was defined as significant increase $(P \leq 0.05)$ of DNA amounts in inoculated plots compared with noninoculated control plots; $n=6$.

TABLE 2. Fusarium spp. DNA in grain of spring barley genotypes in $2013^{2}$

\begin{tabular}{|c|c|c|c|c|c|c|c|c|}
\hline \multirow[b]{3}{*}{ Inoculum } & \multicolumn{8}{|c|}{ Fusarium spp. DNA in pg/ng of barley DNA } \\
\hline & \multicolumn{2}{|c|}{ Ingrid } & \multicolumn{2}{|c|}{ BC Ingrid-mlo5 } & \multicolumn{2}{|c|}{ Pallas } & \multicolumn{2}{|c|}{ BC Pallas-mlo5 } \\
\hline & Cont & Inoc & Cont & Inoc & Cont & Inoc & Cont & Inoc \\
\hline Fusarium culmorum & $0.01 \mathrm{a}$ & $1.07 \mathrm{c}$ & $0.01 \mathrm{a}$ & $0.67 \mathrm{bc}$ & $0.01 \mathrm{a}$ & $0.80 \mathrm{bc}$ & $0.02 \mathrm{a}$ & $0.50 \mathrm{~b}$ \\
\hline F. graminearum & $0.03 \mathrm{a}$ & $0.51 \mathrm{~b}$ & $0.04 \mathrm{a}$ & $0.29 \mathrm{ab}$ & $0.04 \mathrm{a}$ & $0.39 \mathrm{~b}$ & $0.05 \mathrm{a}$ & $0.26 \mathrm{ab}$ \\
\hline F. avenaceum & $0.05 \mathrm{a}$ & $0.09 \mathrm{a}$ & $0.04 \mathrm{a}$ & $0.18 \mathrm{a}$ & $0.05 \mathrm{a}$ & $0.11 \mathrm{a}$ & $0.11 \mathrm{a}$ & $0.11 \mathrm{a}$ \\
\hline F. tricinctum & $0.07 \mathrm{a}$ & $0.01 \mathrm{a}$ & $0.12 \mathrm{a}$ & $0.03 \mathrm{a}$ & $0.01 \mathrm{a}$ & $0.01 \mathrm{a}$ & $0.02 \mathrm{a}$ & $0.12 \mathrm{a}$ \\
\hline F. langsethiae & $0.85 \mathrm{a}$ & $1.54 \mathrm{a}$ & $1.17 \mathrm{a}$ & $1.32 \mathrm{a}$ & $1.07 \mathrm{a}$ & $0.78 \mathrm{a}$ & $0.85 \mathrm{a}$ & $0.72 \mathrm{a}$ \\
\hline F. sporotrichioides & $0.00 \mathrm{a}$ & $0.79 \mathrm{c}$ & $0.01 \mathrm{a}$ & $0.55 \mathrm{bc}$ & $0.01 \mathrm{a}$ & $0.41 \mathrm{abc}$ & $0.00 \mathrm{a}$ & $0.24 \mathrm{ab}$ \\
\hline
\end{tabular}

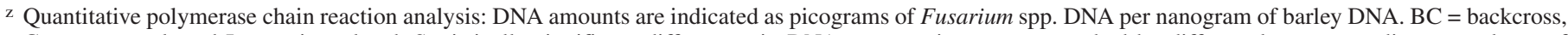
Cont $=$ control, and Inoc $=$ inoculated. Statistically significant differences in DNA amounts in rows are marked by different letters according to analyses of variance results. Inoculation success was defined as significant increase $(P \leq 0.05)$ of DNA amounts in inoculated plots compared with noninoculated control plots; $n=6$. 
infestation following inoculation with Fusarium spp. in the field was visible in 2013, too. However, this effect was not statistically significant, likely due to the lower inoculation success (Table 2). In 2011 and 2012, we inoculated with $F$. culmorum only. This again resulted, by trend in 2011 and significantly in 2012, in lower fungal DNA content in grain of BC mlo5 lines when compared with WT MLO lines.

In summary, there was no $M L O$ genotype-dependent difference in Fusarium spp. DNA content of grain without inoculation. By contrast, $\mathrm{BC}$ mlo5 lines were less field susceptible to grain infestation following inoculation with single Fusarium spp.

Influence of mlo resistance on the impact of $R$. collocygni. We further quantified $R$. collo-cygni DNA in barley grain deriving from noninoculated field plots over four consecutive years (2010 to 2013). A comparison of different trial years showed the highest $R$. collo-cygni infestation in 2012 (682.47 pg/ng of total DNA), followed by 2010 (256.11 pg/ng of total DNA) and 2011 (173.28 pg/ng of total DNA). In 2013, we determined the lowest infestation rate $(86.80 \mathrm{pg} / \mathrm{ng}$ of total DNA). No consistent difference in infestation levels could be observed over the years between the WT $M L O$ Pallas and Ingrid. When we compared WT $M L O$ genotypes of Ingrid and Pallas with their near-isogenic BC mlo5 lines, we detected no significant differences in $R$. collo-cygni infestation in any year of trial (Table 3 ). However, $R$. collo-cygni DNA content was consistently lower in the BC Ingrid-mlo5 line compared with the Ingrid WT line. No such consistent tendency was observed in the Pallas background.

In summary, quantification of $R$. collo-cygni DNA in naturally infected barley grain did not detect significant differences in grain infestation that could be explained by the allele present at the $M L O$ locus.

\section{DISCUSSION}

Our data suggest that powdery-mildew-resistant mlo5 spring barley lines do not show enhanced field susceptibility toward grain infestation by partially seed-transmitted necrotrophic or hemibiotrophic ascomycete fungi of the Fusarium genus or $R$. collocygni. On the contrary, tested mlo5 genotypes appeared similar or in several cases less infested with corresponding Fusarium pathogens than the respective near-isogenic WT lines. Although environmental factors, such as humidity and precipitation, might have influenced the natural infection conditions over the years (Meteorological Network of the Bavarian State Research Center for Agriculture 2014, Supplementary Table S2), data show a rather protective mlo5 effect for F. culmorum infestation over 4 years with inoculation. F. culmorum is relevant for European spring barley production (Nielsen et al. 2011) and, in our opinion, the most reliable leads to inoculation success in the field (Linkmeyer et al. 2013). For other Fusarium spp. (F. avenaceum, F. sporotrichioides, F. graminearum, F. tricinctum, and F. langsethiae), data from 1 or 2 years of trials supported the idea that mlo5 genotypes are at least not more susceptible to Fusarium grain infestation. This also suggests that the type of toxin produced by individual Fusarium spp. is possibly not decisive for the infection success on $m l o 5$ barley genotypes.

Previous studies have demonstrated enhanced susceptibility of mlo5 genotypes to M. oryzae (Jarosch et al. 1999), F. graminearum (Jansen et al. 2005) and toxic culture filtrates of B. sorokiniana (Kumar et al. 2001). These studies were carried out under controlled environmental conditions, with high inoculum pressure and partially with excised plant organs. Our present results suggest that Fusarium spp. and $R$. collo-cygni grain infestation as one final outcome of a seasonal host-parasite interaction is not affected by a trade-off with mlo5-mediated powdery mildew resistance under field conditions. As grain infestation is highly relevant for malting quality and symptom formation is unspecific for Fusarium spp. and $R$. collo-cygni infection on barley spikes, quantification of corresponding fungal DNA was chosen as appropriate tool for assessing infestation.
Little information is available about the influence of the $M L O$ genotype on spike infections in barley. Jansen et al. (2005) demonstrated a clear difference in progressive penetration success of $F$. graminearum into barley $M L O$ or $m l o 5$ aleurone and endosperm of isolated caryopses (Jansen et al. 2005). Beside a decomposition of corresponding cells, large lesions were identified in the hypodermis of BC Ingrid-mlo5 and BC Pallas-mlo5. Higher susceptibility of BC mlo5 lines to lesion formation was independent on the ability of the fungus to produce trichothecenes. Our data do not support enhanced Fusarium susceptibility of the same $\mathrm{BC}$ mlo5 lines to grain infestation in the field. No significant differences in $F$. graminearum DNA amounts were detected for different $M L O$ genotypes of Ingrid and Pallas in 2013 (Table 2). Rather less $F$. graminearum DNA was detected in BC mlo5 lines. In particular in 2010 grain infestation by several other Fusarium spp. was even lower in BC mlo5 lines than in WT $M L O$ lines after inoculation. Experimental conditions might have caused differences in the interaction outcome between the study of Jansen et al. (2005) and the present study. In vitro inoculation of barleyisolated caryopses occurred after removing glumes, lemma, and palea and by direct application of macroconidia on sterilized tissue (Jansen et al. 2005). Under field trial conditions, fungal spores had to overcome several barriers before a successful infection of caryopses might take place. Therefore, higher susceptibility of mlo5 caryopses to fungal penetration might not manifest when considering intact plants. This questions the relevance of enhanced mlo5 tissue susceptibility to necrotization under high Fusarium spp. pressure for field conditions and, hence, for decision making in plant breeding and integrated disease management. However, our data do not exclude the possibility that mlo5 genotypes might show enhanced susceptibility to Fusarium spp. under environmental conditions that did not take place during our time frame of observation. It is further important to note that mlo5mediated powdery mildew resistance is sensitive to abiotic stress conditions such as release from soil water shortage and heat (Schwarzbach 2001). Therefore, we cannot exclude the possibility that environment-genotype interactions have masked possible negative mlo5 effects on basal Fusarium resistance. However, in four consecutive years with inoculations in the field, BC mlo5 lines were consistently less susceptible to $F$. culmorum. We made similar observations for Fusarium spp. other than F. graminearum or F. culmorum which produce toxins; namely, the trichothecene A producer $F$. sporotrichioides or the enniatin and beauvericin producer F. avenaceum. Therefore, we conclude that the use of mlo alleles in spring barley breeding and disease management likely does not come with a general trade-off in regard to Fusarium grain infections.

McGrann et al. (2014) demonstrated enhanced susceptibility of diverse mlo mutant genotypes to RLS symptoms under natural infection conditions. The mlo effects on RLS symptoms were further confirmed under controlled conditions. However, previous triennial field trial studies did not observe similar effects but rather found reduced susceptibility to Rhynchosporium leaf spots and RLS (Makepeace et al. 2007). Influence of environmental factors on genotypes differing at the $M L O$ locus was considered as a possible

TABLE 3. Ramularia collo-cygni DNA in grain of noninoculated spring barley genotypes $^{\mathrm{z}}$

\begin{tabular}{lcccc}
\hline & \multicolumn{4}{c}{$R$. collo-cygni DNA in pg/ng of total DNA } \\
\cline { 2 - 5 } Year & Ingrid & BC Ingrid-mlo5 & Pallas & BC Pallas-mlo5 \\
\hline 2010 & $228.77 \mathrm{a}$ & $127.20 \mathrm{a}$ & $231.47 \mathrm{a}$ & $394.03 \mathrm{a}$ \\
2011 & $220.10 \mathrm{a}$ & $195.83 \mathrm{a}$ & $153.17 \mathrm{a}$ & $124.00 \mathrm{a}$ \\
2012 & $779.19 \mathrm{a}$ & $414.31 \mathrm{a}$ & $798.08 \mathrm{a}$ & $738.28 \mathrm{a}$ \\
2013 & $107.48 \mathrm{a}$ & $71.98 \mathrm{a}$ & $57.37 \mathrm{a}$ & $110.37 \mathrm{a}$ \\
\hline
\end{tabular}

$\mathrm{z}$ Quantitative polymerase chain reaction analysis: DNA amounts are indicated as picograms per nanogram of total DNA. Analyses of variance calculation could not detect any significant difference in DNA amounts between the wild type and backcross (BC) mlo5 lines. Years: 2010, $n=2$ (BC Ingridmlo5) and $n=3$ (others); 2011, $n=3 ; 2012, n=6$; and 2013, $n=6$. 
reason for conflicting results. No information is available on whether fungal biomass or DNA content correlated with RLS symptoms on diverse $M L O$ genotypes under field conditions. In addition to the perception of $R$. collo-cygni as a leaf pathogen, the fungus has the potential to infect spikes (Matusinsky et al. 2011; Oxley and Havis 2004). With regard to this, the present study has not detected an effect of mlo on $R$. collo-cygni grain infestation. In spite of annual variability in natural infection levels, we did not find significant differences between WT lines and BC mlo5 genotypes of Ingrid and Pallas. However, there are several possible inoculum sources for $R$. collo-cygni (Frei et al. 2007) and, thus, our data cannot be generalized in terms of susceptibility of mlo mutant genotypes to $R$. collo-cygni. Tissue-specific differences may well be responsible for the lack of mlo impact on grain infestation by $R$. collo-cygni. Nevertheless, seed transmission is considered to be an important method of distribution for R. collo-cygni (Havis et al. 2014) and our data suggest that there is no general pleiotropic negative effect of $m l o$-mediated powdery mildew resistance on seed contamination with $R$. collo-cygni.

It was discussed that mlo mutants might show a generally reduced basal resistance to cell-death-inducing pathogens (Jansen et al. 2005; Jarosch et al. 1999; Kumar et al. 2001). Although fungi appear to penetrate deeper into tissue of mlo5 mutant than WT $M L O$ genotypes (Jansen et al. 2005; Jarosch et al. 1999), no quantification of fungal biomass on intact plants was carried out. Similar studies with Arabidopsis thaliana demonstrated that powdery-mildewresistant mlo mutants developed more disease symptoms when inoculated with necrotrophic pathogens. However, disease symptom development did not consistently correlate with enhanced fungal biomass (Consonni et al. 2006). Enhanced susceptibility of mlo5 mutants to $B$. sorokiniana was more reproducible when injecting toxic fungal culture filtrates than when inoculating with actual spore suspensions (Kumar et al. 2001). Together, this raises the question of whether mlo5 mutants are indeed more susceptible to fungal necrotrophs or hemibiotrophs or, rather, develop more symptoms when challenged by cell-death-inducing agents. Virtually no information is available that would help in answering this question, in particular when considering field studies (Brown and Rant 2013). Loss-of-function mlo mutants do not only show powdery mildew resistance but also spontaneous defense responses, necrotic mlo spots, early senescence, and enhanced expression of defense genes, regardless of whether they are inoculated with biotrophic powdery mildew or with hemibiotrophic pathogens (Jarosch et al. 2003; Peterhänsel et al. 1997; Piffanelli et al. 2002; Schultheiss et al. 2003; Wolter et al. 1993). Therefore, it appears possible that inconsistent results on susceptibility of mlo mutant genotypes to hemibiotrophs results from mlo-mediated enhanced defense potential on the one hand, which might affect the pathogen during a biotrophic phase; and, on the other hand, a reduced threshold of mlo mutants for undergoing cell death when confronted with fungal toxin effectors during a necrotrophic phase. This gets even more complex considering that cell-death-inducing fungi can pursue a wide range of individual infection strategies (Horbach et al. 2011) and change trophism (Lee and Rose 2010) and relation to their host plant (Newton et al. 2010) within their life cycle. In particular, it may explain the differences between the studies of different necrotrophic pathogens in field and laboratory experiments in the regard to mlo resistance. Certainly, mlo resistance is a valuable tool to study differences in host-parasite interaction of different hemibiotrophic and necrotrophic cereal pathogens to further elucidate similarities and differences between biotrophic and nonbiotrophic pathogens in host-parasite interaction.

Genetic loss of susceptibility is considered to be a valuable tool in plant breeding but might come with a trade-off (Brown and Rant 2013; Hückelhoven et al. 2013). Loss of WT MLO function leads to powdery mildew resistance in many plant species (Acevedo-Garcia et al. 2014). Most recently, genome editing of hexaploid bread wheat succeeded in generation of powdery-mildew-resistant mlo mutant wheat (Wang et al. 2014). Possible implementation of mlo resistance into wheat breeding programs has to consider $m l o$ effects on basal resistance to Fusarium spp., Magnaporthe spp., and $R$. collo-cygni. Based on our data, an increased field susceptibility of mlo mutant genotypes to grain infestation by Fusarium spp. and $R$. collo-cygni grain infection cannot be declared. However, the outcome of an interaction of mlo mutants with fungal agents might change depending on environmental impacts or plant organ- or plant age-dependent factors. We recommend a reconsideration of the mlo mutant effect on field susceptibility to cell-death-inducing pathogens.

\section{ACKNOWLEDGMENTS}

This work was financially supported by funds from the Research Association of the German Food Industry and the Bavarian State Ministry of Food, Agriculture and Forestry. We thank C. Hutter, N. Metz, and F. Gebauer for their technical support.

\section{LITERATURE CITED}

Acevedo-Garcia, J., Kusch, S., and Panstruga, R. 2014. Magical mystery tour: MLO proteins in plant immunity and beyond. New Phytol. 204:273-281.

Bennett, J. W., and Klich, M. 2003. Mycotoxins. Clin. Microbiol. Rev. 16: 497-516.

Bottalico, A., and Perrone, G. 2002. Toxigenic Fusarium species and mycotoxins associated with head blight in small-grain cereals in Europe. Eur. J. Plant Pathol. 108:611-624.

Brown, J. K. M. 2002. Yield penalties of disease resistance in crops. Curr. Opin. Plant Biol. 5:339-344.

Brown, J. K. M., and Rant, J. C. 2013. Fitness costs and trade-offs of disease resistance and their consequences for breeding arable crops. Plant Pathol. 62(Suppl. S1):83-95.

Brown, N. A., Urban, M., van de Meene, A. M., and Hammond-Kosack, K. E. 2010. The infection biology of Fusarium graminearum: Defining the pathways of spikelet to spikelet colonisation in wheat ears. Fungal Biol. 114:555-571.

Büschges, R., Hollricher, K., Panstruga, R., Simons, G., Wolter, M., Frijters, A., van Daelen, R., van der Lee, T., Diergaarde, P., Groenendijk, J., Töpsch, S., Vos, P., Salamini, F., and Schulze-Lefert, P. 1997. The barley mlo gene: A novel control element of plant pathogen resistance. Cell 88:695-705.

Consonni, C., Humphry, M. E., Hartmann, H. A., Livaja, M., Durner, J., Westphal, L., Vogel, J., Lipka, V., Kemmerling, B., Schulze-Lefert, P., Somerville, S. C., and Panstruga, R. 2006. Conserved requirement for a plant host cell protein in powdery mildew pathogenesis. Nat. Genet. 38: 716-720.

Frei, P., Gindro, K., Richter, H., and Schürch, S. 2007. Direct PCR detection and epidemiology of Ramularia collo-cygni associated with barley necrotic leaf spots. J. Phytopathol. 155:281-288.

Hackett, C. A., Meyer, R. C., and Thomas, W. T. B. 2001. Multi-trait QTL mapping in barley using multivariate regression. Genet. Res. 77:95-106.

Havis, N. D., Brown, J. K. M, Clemente, G., Frei, P., Jedryczka, M., Kaczmarek, J., Kaczmarek, M., Matusinsky, P., McGrann, G. R. D., Pereyra, S., Piotrowska, M., Sghyer, H., Tellier, A., and Hess, M. 2015. Ramularia collo-cygni - an emerging pathogen of barley crops. Phytopathology 105:895-904.

Havis, N. D., Maguire, K., Knight, S. M., and Oxley, S. J. P. 2011. Ramularia collo-cygni - an increasing problem for barley growers in Southern Britain. Asp. Appl. Biol. 106:131-136.

Havis, N. D., Nyman, M., and Oxley, S. J. P. 2014. Evidence for seed transmission and symptomless growth of Ramularia collo-cygni in barley (Hordeum vulgare). Plant Pathol. 63:929-936.

Horbach, R., Navarro-Quesada, A. R., Knogge, W., and Deising, H. B. 2011. When and how to kill a plant cell: Infection strategies of plant pathogenic fungi. J. Plant Physiol. 168:51-62.

Hückelhoven, R., Eichmann, R., Weis, C., Höfle, C., and Pröls, R. K. 2013. Genetic loss of susceptibility: A costly route to disease resistance? Plant Pathol. 62:56-62.

Jansen, C., von Wettstein, D., Schafer, W., Kogel, K.-H., Felk, A., and Maier, F. J. 2005. Infection patterns in barley and wheat spikes inoculated with wild-type and trichodiene synthase gene disrupted Fusarium graminearum. Proc. Natl. Acad. Sci. U.S.A. 102:16892-16897.

Jarosch, B., Jansen, M., and Schaffrath, U. 2003. Acquired resistance functions in mlo barley, which is hypersusceptible to Magnaporthe grisea. Mol. PlantMicrobe Interact. 16:107-114. 
Jarosch, B., Kogel, K.-H., and Schaffrath, U. 1999. The ambivalence of the barley Mlo locus: Mutations conferring resistance against powdery mildew (Blumeria graminis $f$. sp. hordei) enhance susceptibility to the rice blast fungus Magnaporthe grisea. Mol. Plant-Microbe Interact. 12:508-514.

Jenkinson, P., and Parry, D. W. 1994. Splash dispersal of conidia of Fusarium culmorum and Fusarium avenaceum. Mycol. Res. 98:506-510.

Joint Research Centre. 2007. Maize seeds sampling and DNA extraction. Report on the Validation of a DNA Extraction Method from Maize Seeds. Document CRLVL04/05X. Directorate General-Joint Research Centre Institute for Health and Consumer Protection Biotechnology \& GMOs Unit. Online publication. http://gmo-crl.jrc.ec.europa.eu/summaries/MIR604_DNAExtr.pdf

Jørgensen, J. H. 1992. Discovery, characterization and exploitation of Mlo powdery mildew resistance in barley. Euphytica 63:141-152.

Kjær, B., Jensen, H. P., Jensen, J., and Jørgensen, J. H. 1990. Associations between three $m l$-o powdery mildew resistance genes and agronomic traits in barley. Euphytica 46:185-193.

Kumar, J., Hückelhoven, R., Beckhove, U., Nagarajan, S., and Kogel, K.-H. 2001. A compromised Mlo pathway affects the response of barley to the necrotrophic fungus Bipolaris sorokiniana (teleomorph: Cochliobolus sativus) and its toxins. Phytopathology 91:127-133.

Lee, S. J., and Rose, J. K. C. 2010. Mediation of the transition from biotrophy to necrotrophy in hemibiotrophic plant pathogens by secreted effector proteins. Plant Signal. Behav. 5:769-772.

Linkmeyer, A. 2012. Fusarium head blight of barley: Epidemiology and hostpathogen interaction. Ph.D. thesis, Technische Universität München http://mediatum.ub.tum.de/doc/1115753/1115753.pdf

Linkmeyer, A., Götz, M., Hu, L., Asam, S., Rychlik, M., Hausladen, H., Hess, M., and Hückelhoven, R. 2013. Assessment and introduction of quantitative resistance to Fusarium head blight in elite spring barley. Phytopathology 103:1252-1259.

Makepeace, J. C., Havis, N. D., Burke, J. I., Oxley, S. J. P., and Brown, J. K. M. 2008. A method of inoculating barley seedlings with Ramularia collo-cygni. Plant Pathol. 57:991-999.

Makepeace, J. C., Oxley, S. J. P, Havis, N. D., Hackett, R., Burke, J. I., and Brown, J. K. M. 2007. Associations between fungal and abiotic leaf spotting and the presence of mlo alleles in barley. Plant Pathol. 56:934-942.

Matusinsky, P., Leisova-Svobodova, L., Gubis, J., Hudcovicova, M., Klcova, L., Gubisova, M., Marik, P., Tvaruzek, L., and Minarikova, V. 2011. Impact of the seed-borne stage of Ramularia collo-cygni in barley seed. J. Plant Pathol. 93:679-689.

McGrann, G. R. D., Stavrinides, A., Russell, J., Corbitt, M. M., Booth, A., Chartrain, L., Thomas, W. T. B., and Brown, J. K. M. 2014. A trade off between mlo resistance to powdery mildew and increased susceptibility of barley to a newly important disease, Ramularia leaf spot. J. Exp. Bot. 65:1025-1037.

McMullen, M., Jones, R., and Gallenberg, D. 1997. Scab of wheat and barley: A re-emerging disease of devastating impact. Plant Dis. 81:1340-1348.

Meteorological Network of the Bavarian State Research Center for Agriculture. 2014. http://www.lfl-design3.bayern.de/agm/

Newton, A. C., Fitt, B. D. L., Atkins, S. D., Walters, D. R., and Daniell, T. J. 2010. Pathogenesis, parasitism and mutualism in the trophic space of microbe-plant interactions. Trends Microbiol. 18:365-373.

Nganje, W. E., Bangsund, D., Leistritz, F., Wilson, W. W., and Tiapo, N. M. 2002. Estimating the economic impact of a crop disease: The case of Fusarium head blight in U.S. wheat and barley. Pages 275-281 in: Natl. Fusarium Head Blight Forum Proc.

Nicolaisen, M., Suproniene, S., Nielsen, L., Lazzaro, I., Spliid, N., and Justensen, A. 2009. Realtime PCR for quantification of eleven individual Fusarium species in cereals. J. Microbiol. Methods 76:234-240.

Nielsen, L. K., Jensen, J. D., Nielsen, G. C., Jensen, J. E., Spliid, N. H., Thomsen, I. K., Justesen, A. F., Collinge, D. B., and Jørgensen, L. N. 2011.
Fusarium head blight of cereals in Denmark: Species complex and related mycotoxins. Phytopathology 101:960-969.

Oxley, S. J. P., and Havis, N. D. 2004. Development of Ramularia collo-cygni on spring barley and its impact on yield. Pages 147-152 in: Proc. Dundee Conf. Crop Prot. Northern Britain.

Parry, D. W., Jenkinson, P., and McLeod, L. 1995. Fusarium ear blight (scab) in small grain cereals-A review. Plant Pathol. 44:207-238.

Peterhänsel, C., Freialdenhoven, A., Kurth, J., Kolsch, R., and Schulze-Lefert, P. 1997. Interaction analyses of genes required for resistance responses to powdery mildew in barley reveal distinct pathways leading to leaf cell death. Plant Cell 9:1397-1409.

Piffanelli, P., Zhou, F., Casais, C., Orme, J., Jarosch, B., Schaffrath, U., Collins, N. C., Panstruga, R., and Schulze-Lefert, P. 2002. The barley MLO modulator of defense and cell death is responsive to biotic and abiotic stress stimuli. Plant Physiol. 129:1076-1085.

Pinnschmidt, H. O., and Sindberg, S. A. 2009. Assessing Ramularia leaf spot resistance of spring barley cultivars in the presence of other diseases. Asp. Appl. Biol. 92:71-80.

Purrington, C. B. 2000. Costs of resistance. Curr. Opin. Plant Biol. 3: 305-308.

Schäfer, P., Hückelhoven, R., and Kogel, K. H. 2004. The white barley mutant albostrians shows a supersusceptible but symptomless interaction phenotype with the hemibiotrophic fungus Bipolaris sorokiniana. Mol. PlantMicrobe Interact. 17:366-373.

Schultheiss, H., Dechert, C., Kiraly, L., Fodor, J., Michel, K., Kogel, K.-H., and Hückelhoven, R. 2003. Functional assessment of the pathogenesisrelated protein PR-1b in barley. Plant Sci. 165:1275-1280.

Schwarzbach, E. 2001. Heat induced susceptibility of mlo-barley to powdery mildew. Czech J. Genet. Plant Breed. 37:82-87.

Stolzenburg, M. C., Aist, J. R., and Israel, H. W. 1984. The role of papillae in resistance to powdery mildew conditioned by the ml-o gene in barley. I Correlative evidence. Physiol. Plant Pathol. 25:337-346.

Summers, R. W., and Brown, J. K. M. 2013. Constraints on breeding for disease resistance in commercially competitive wheat cultivars. Plant Pathol. 62:115-121.

Taylor, J. M. G., Paterson, L. J., and Havis, N. D. 2010. A quantitative realtime PCR assay for the detection of Ramularia collo-cygni from barley (Hordeum vulgare). Lett. Appl. Microbiol. 50:493-499.

Tekauz, A., McCallum, B., and Gilbert, J. 2000. Review: Fusarium head blight of barley in western Canada. Can. J. Plant Pathol. 22:9-16.

Thomas, W. T. B., Baird, E., Fuller, J. D., Lawrence, P., Young, G. R., Russell, J., Ramsay, L., Waugh, R., and Powell, W. 1998. Identification of a QTL decreasing yield in barley linked to Mlo powdery mildew resistance. Mol. Breed. 4:381-393.

Torp, M., and Nirenberg, H. 2004. Fusarium langsethiae sp. nov. on cereals in Europe. Int. J. Food Microbiol. 95:247-256.

Walters, D. R., Havis, N. D., and Oxley, S. J. P. 2008. Ramularia collo-cygni: The biology of an emerging pathogen of barley. FEMS Microbiol. Lett. 279:1-7.

Wang, Y., Cheng, X., Shan, Q., Zhang, Y., Liu, J., Gao, C., and Qiu, J. L. 2014. Simultaneous editing of three homoeoalleles in hexaploid bread wheat confers heritable resistance to powdery mildew. Nat. Biotechnol. 32: 947-951.

Windels, C. E. 2000. Economic and social impacts of Fusarium head blight: Changing farms and rural communities in the Northern Great Plains. Phytopathology 90:17-21.

Wolter, M., Hollricher, K., Salamini, F., and Schulze-Lefert, P. 1993. The mlo resistance alleles to powdery mildew infection in barley trigger a developmentally controlled defense mimic phenotype. Mol. Gen. Genet. 239:122-128. 